УДК 339.944 .2

\title{
НОВЫЕ УСЛОВИЯ ДЛЯ РАСШИРЕНИЯ ПРИСУТСТВИЯ РОССИЙСКИХ ЭНЕРГОКОМПАНИЙ НА ЭЛЕКТРОЭНЕРГЕТИЧЕСКИХ РЫНКАХ АРАБСКИХ СТРАН ЗАПАДНОЙ АЗИИ
}

\author{
(C) 2012 г. A. Н. Нарова
}

\section{Институт стран Азии и Африки при МГУ им. Ломоносова, г. Москва}

Рассмотрены вопросы, связанные с реформированием электроэнергетики в арабских странах Западной Азии. В разной степени изменения затронули все государства региона. В настоящее время спрос на электроэнергию, в основном, удовлетворяется за счет собственного производства. Установлено, что спрос на электроэнергию имеет устойчивую тенденцию к росту, а его покрытие будет осуществляться за счет строительства собственных генерирующих мощуностей с привлечением ведущих энергетических компаний мира. Это создает предпосылки для расширения присутствия российских энергокомпаний на электроэнергетических рынках рассматриваемых стран, прежде всего, за счет углубления взаимовыгодной кооперачии с ведущиими российскими и зарубежными энергетическими компаниями и финансовыми структурами.

Ключевые слова: арабские страны западной Азии; реформирование электроэнергетики; электроэнергетические рынки; российские энергетические компании; сотрудничество и коопераичия.

The article discusses the questions of electricity market reform in the Arab countries of Western Asia. The process has started in all countries. Currently, the demand for electricity is mainly met by domestic production. The demand for electricity in the region will steadily increase in the nearest future, and it will be provided through the construction of new generating facilities in partnership with world leading energy companies. This situation gives good opportunities for Russian power companies to expand cooperation in the electricity sector of the Arab countries of Western Asia, especially by deepening cooperation with leading Russian and foreign energy companies and financial institutions.

Key words: the Arab countries of Western Asia; reform of electricity sector; electricity markets; Russian energy companies; collaboration and cooperation.

В конце XX - начале XXI вв. арабские страны Западной Азии приступили к реструктуризации своих электроэнергетических секторов, следуя основным мировым тенденциям развития этой важнейшей отрасли хозяйства. Рассматриваемые государства находятся на различных стадиях протекания данного объективного процесса, но изменения были начаты повсеместно. В результате преобразований формируются новые условия функционирования рынков электроэнергии, что интересно с точки зрения развития мирового бизнеса в целом, и для России в частности. В связи с этим представляются актуальными анализ результатов реформирования электроэнергетики арабских стран Западной Азии и выявление основных направлений сотрудничества.

Исторически во времена СССР сотрудничество сводилось к безвозмездной помощи государствам, лояльным к советскому строю, носило политический характер и практически не имело экономических оснований и выгод. Взаимодействие в энергетической сфере, 
выражавшееся в первую очередь в возведении специалистами из союзных республик современных энергообъектов на территории арабских государств, а также в проведении регулярных работ по модернизации и реконструкции имеющихся объектов, проходило по линии «ВО «Технопромэкспорт» - предприятия системы Госкомитета по внешнеэкономическим связям. В 1950-1980-х гг. в этих странах было построено 8 ТЭС, 11 ГЭС, проложены тысячи километров линий электропередач (ЛЭП).

B тот период основными партнерами Co- ветского Союза по энергетическому диалогу в регионе Западной Азии стали Ирак, Сирия и Йемен. Конкретные результаты работ, выполненные советскими специалистами в указанных странах, представлены в таблице 1.

Как видно из данных таблицы 1, за 30 лет при содействии СССР в арабских странах было введено 4057,8 МВт электроэнергетических мощностей (условно примем, что на ТЭС «Аль-Шемаль» и ГЭС «Аль-Багдади» работы были проведены в полном объеме). Для сравнения: в России прогнозные ежегодные объемы вводов генерирующего оборудо-

Таблица 1

\section{Электроэнергетические проекты, реализованные «ВО «Технопромэкспорт»} в Ираке, Сирии и Йемене*

\begin{tabular}{|c|c|c|c|c|}
\hline №№ & Страна & $\begin{array}{c}\text { Год ввода } \\
\text { в эксплуатацию }\end{array}$ & $\begin{array}{l}\text { Наименование } \\
\text { объекта }\end{array}$ & $\begin{array}{c}\text { Основные характеристики, } \\
\text { объем работ }\end{array}$ \\
\hline 1 & \multirow{6}{*}{ Ирак } & 1975 & ТЭС «Наджибия» & 200 МВт. Проект 100\% \\
\hline 2 & & 1982 & ТЭС «Нассирия» & 540 МВт. Проект 100\% \\
\hline 3 & & 1985 & $\begin{array}{c}\text { ГЭС } \\
\text { «Аль-Кадиссия» } \\
\text { (Хадита) }\end{array}$ & 500 МВт. Проект 100\% \\
\hline 4 & & & $\begin{array}{c}\text { ТЭС } \\
\text { «Аль-Шемаль» }\end{array}$ & $\begin{array}{c}1400 \text { МВт. Поставка и } \\
\text { монтаж электроэнергети- } \\
\text { ческого оборудования }\end{array}$ \\
\hline 5 & & 1989 & $\begin{array}{c}\text { ГЭС } \\
\text { «Аль-Багдади» }\end{array}$ & $\begin{array}{c}400 \text { МВт. Поставка и мон- } \\
\text { таж строительного обору- } \\
\text { дования }\end{array}$ \\
\hline 6 & & & $\begin{array}{c}\text { ЛЭП протяжен- } \\
\text { ностью } 500 \text { км }\end{array}$ & 132 кВ. Проект 100\% \\
\hline 7 & \multirow{5}{*}{ Сирия } & 1960 & ГЭС «Хома» & 3 МВт. Проект 100\% \\
\hline 8 & & 1963 & ГЭС «Растан» & 8,8 МВт. Проект 100\% \\
\hline 9 & & 1978 & ГЭС «Табка» & 800 МВт. Проект 100\% \\
\hline 10 & & 1989 & ГЭС «Аль-Баас» & 81 МВт. Проект 100\% \\
\hline 11 & & & $\begin{array}{l}\text { ЛЭП протяжен- } \\
\text { ностью } 4100 \text { км }\end{array}$ & 110-220 кВ. Проект 100\% \\
\hline 12 & Йемен & 1987-1992 & $\begin{array}{l}\text { ТЭС и опресни- } \\
\text { тельный ком- } \\
\text { плекс в г. Адене }\end{array}$ & 125 МВт. Проект 100\% \\
\hline
\end{tabular}

* Составлено по материалам [5]. 
вания после прохождения зимнего максимума в 2012-2018 гг. составляют от 1582,2 до 4534,2 МВт [4].

Для того, чтобы хотя бы примерно оценить затраты, которые осуществил СССР в электроэнергетику стран рассматриваемого региона, воспользуемся следующими данными:

1. Стоимость строительства ТЭС на территории России в среднем составляет около 2000 долл. США за 1 кВт (по информации Минэнерго России);

2. Средняя цена строительства ГЭС составляет от 1,5 до 2 млн. долл. США за $1 \mathrm{MB}$ (по информации ОАО «РусГидро»);

3. Стоимость строительства 1 км ЛЭП (напряжением 220 кВ) на территории РФ составляет от 15 до 20 млн. руб. и в значительной степени зависит от местности (по информации ОАО «ФСК ЕЭС»).

Сохраним допущение о том, что работы на ТЭС «Аль-Шемаль» и ГЭС «Аль-Багдади» в Ираке были проведены в полном объеме. Примем, что все ЛЭП на территории арабских стран были сооружены напряжением 220 кВ, а также, что 1 долл. США примерно равен 30 руб. Результаты расчетов приведены в таблице 2.

Таким образом, за 30 лет СССР вложил в развитие электроэнергетического хозяйства Ирака, Сирии и Йемена примерно 9,511,2 млрд. долл. Объемы капиталовложе-

Таблица 2

Оценка капиталовложений, осуществленных СССР в электроэнергетику арабских стран

\begin{tabular}{|c|c|c|c|c|}
\hline №№ & Страна & Наименование объекта & $\begin{array}{c}\text { Основные характери- } \\
\text { стики }\end{array}$ & $\begin{array}{c}\text { Оценка стоимости, } \\
\text { млн. долл. США }\end{array}$ \\
\hline 1 & \multirow{6}{*}{ Ирак } & ТЭС «Наджибия» & $200 \mathrm{MBT}$ & 400 \\
\hline 2 & & ТЭС «Нассирия» & $540 \mathrm{MBT}$ & 1080 \\
\hline 3 & & $\begin{array}{c}\text { ГЭС «Аль-Кадиссия» } \\
\text { (Хадита) }\end{array}$ & $500 \mathrm{MBT}$ & $750-1000$ \\
\hline 4 & & ТЭС «Аль-Шемаль» & $1400 \mathrm{MBT}$ & 2800 \\
\hline 5 & & ГЭС «Аль-Багдади» & $400 \mathrm{MBT}$ & $600-800$ \\
\hline 6 & & $\begin{array}{c}\text { ЛЭП протяженностью } 500 \\
\text { км }\end{array}$ & 132 кВ & $250-334$ \\
\hline \multicolumn{4}{|r|}{ ИТОГО по Ираку: } & $5880-6414$ \\
\hline 7 & \multirow{5}{*}{ Сирия } & ГЭС «Хома» & $3 \mathrm{MBT}$ & $4,5-6$ \\
\hline 8 & & ГЭС «Растан» & $8,8 \mathrm{MBT}$ & $13,2-17,6$ \\
\hline 9 & & ГЭС «Табка» & $800 \mathrm{MBT}$ & $1200-1600$ \\
\hline 10 & & ГЭС «Аль-Баас» & $81 \mathrm{MBT}$ & $121,5-162$ \\
\hline 11 & & $\begin{array}{c}\text { ЛЭП протяженностью } \\
4100 \text { км }\end{array}$ & $110-220$ кВ & $2050-2733$ \\
\hline \multicolumn{4}{|r|}{ ИТОГО по Сирии: } & $3389,2-4518,6$ \\
\hline 12 & Йемен & $\begin{array}{l}\text { ТЭС и опреснительный } \\
\text { комплекс в г. Адене }\end{array}$ & $125 \mathrm{MBT}$ & 250 \\
\hline & & & $\begin{array}{l}\text { ИТОГО по трем } \\
\text { странам: }\end{array}$ & $9519,2-11182,6$ \\
\hline
\end{tabular}


ний в развитие электроэнергетики России в 2012 г. оцениваются в 33,5 млрд. долл., а всего за период 2012-2018 гг. планируется инвестировать 152,5 млрд. долл., в том числе по генерирующим объектам почти 95 млрд. и электрическим сетям 220 кВ и выше 57,5 млрд. [4].

Следует отметить, что развитие советскоарабских торгово-экономических связей сопровождалось нарастанием внешней задолженности ряда арабских государств, которая к 1991 г. достигла около 35 млрд. долл. США. Неплатежи Сирии перед Россией составили 13 млрд. долл., из которых 9,78 млрд. было списано в 2005 г. в обмен на обещания Дамаска расширить военно-техническое сотрудничество двух стран [1]. Ираку в 2008 г. Россия простила 11,1 млрд. из 12 млрд. долга перед Советским Союзом. Оставшиеся 900 млн. также планируется списать, но при условии, что иракское правительство будет выполнять специальную программу Международного валютного фонда по восстановлению экономики своей страны и допускать российские компании на свой рынок на льготных условиях [3].

В 1990-е гг., в сложный период социально-экономического кризиса для новой России, сотрудничество с арабским миром почти полностью прекратилось. Это было связано, прежде всего, с переменой основного внешнеторгового партнера: ставка была сделана на развитие отношений с Западом в ущерб сотрудничеству с арабскими государствами. Важным фактором стало сокращение производства и снижение промышленного потенциала в России, потеря отечественными компаниями конкурентоспособности, свою негативную роль сыграли и политические причины. Единственной сферой, в которой сотрудничество не было прервано полностью, стала энергетика, так как контракты, подписанные в предшествующий период, имели долгосрочный характер.

Наиболее заметным проектом в сфере электроэнергетики стало строительство на реке Евфрат гидроэлектростанции «Тишрин» египетской компанией «General Company for Land Reclamation» при участии российских компаний «Технопромэкспорт» и «Силовые машины». Комплекс электростанции включает шесть силовых турбин суммарной мощно- стью 630 МВт. В настоящее время это вторая по мощности ГЭС в Сирии после ГЭС «Табка». В 1996 г. российскими специалистами был осуществлен перевод работы котлов на ТЭС с одноименным названием с мазута на газ.

В 2000-е гг. в отношениях России с арабским миром начали происходить существенные изменения. После ряда встреч и переговоров на высшем уровне торгово-экономическому сотрудничеству был дан мощный стимул к развитию. На сегодняшний день сложилась благоприятная ситуация для более глубокого проникновения российских компаний на электроэнергетические рынки арабских государств вследствие ряда причин.

- расширение арабо-российского сотрудничества во всех сферах соответствует внешнему курсу и геополитическим интересам России в регионе;

- арабские страны в той или иной форме проводят реформы в электроэнергетических секторах, меняют формы собственности, запускают программы по привлечению иностранных инвестиций, опыта и технологий в отрасль;

- почти все арабские государства Западной Азии заявляют о желании диверсифицировать свои источники энергии, о готовности развивать атомную и возобновляемую энергетику;

- российские компании, в свою очередь, обладают достаточным опытом и технологиями в области строительства, ремонта и модернизации электростанций, а также электросетевой и другой энергетической инфраструктуры.

Рассмотрим изменения, происходящие на электроэнергетических рынках арабских стран Западной Азии, более подробно. Государства региона сталкиваются с проблемой нехватки генерирующих мощностей из-за быстро растущего спроса на электроэнергию, увеличение которых требует существенных капиталовложений. Для привлечения дополнительных инвестиций в строительство новых и модернизацию уже имеющихся энергообъектов правительства этих стран начали реструктуризацию и приватизацию электроэнергетического сектора.

Наибольших успехов в данном процессе достигла Иордания. В 1997 г. Совет мини- 
стров одобрил курс на реформирование электроэнергетики, нацеленный на обеспечение притока инвестиций в отрасль и повышение ее эффективности в свете прогнозируемого роста спроса. Для достижения этих задач была запланирована реорганизация с разделением сфер производства, передачи и распределения между различными компаниями, а также приватизация генерирующих и сбытовых компаний.

В начале февраля 1999 г. компания «National Electric power Company» (NEPCO), которая на тот момент сосредоточила в своих руках все стадии технологического процесса, разделилась на три отдельные компании:

1) «Central Electricity Generating Company» (CEGCO), ответственную за производство электроэнергии;

2) «Electricity Distribution Company» (EDCO), занимающуюся распределением электроэнергии;

3) собственно NEPCO, в ведении которой осталась передача электроэнергии по высоковольтным линиям.

В 2001 г. была создана независимая Комиссия по регулированию электроэнергетики Иордании, которая осуществляет выдачу и контроль над соблюдением лицензий компаниями, работающими в отрасли, рассмотрение и установку оптовых и розничных тарифов, контроль за соблюдением компаниями различных стандартов и норм, а также защиту прав и интересов потребителей.

В ноябре 2002 г. Совет министров одобрил стратегию приватизации электроэнергетических компаний, согласно которой планировалось продать до $60 \%$ акций, принадлежащих государству, в CEGCO, 100\% - в EDCO и 55,4\% — в «Irbid District Electricity Company» (IDECO), которая занимается производством и распределением электроэнергии в северной части страны, а NEPCO оставить полностью в государственной собственности.

В марте 2004 г. стартовал процесс куплипродажи CEGCO, в апреле начались торги, а к августу 2006 г. были получены предложения от четырех потенциальных инвесторов. В мае 2007 г. 51\% акций приобрел консорциум «ENARA», включающий в себя в качестве лидера компанию «Jordan Dubai Energy and Infrastructure», а также малазийскую
«Malakoff Berhad» и греческую «Consolidated Contractors Group», 9\% акций купила компания «Social Security Corporation», а 40\% акций остались у государства. Сделку стоимостью 140 млн. долл. США с консорциумом «ENARA» закрыли в октябре 2007 г.

Приватизация EDCO и IDECO началась в июне 2006 г. в рамках международного процесса торгов. Спустя год были получены три предложения на покупку IDECO и лишь одно - на EDCO. В ноябре 2007 г. Совет министров одобрил куплю-продажу обеих компаний за 104 млн. долл. компанией «Kingdom Electricity Company» (KEC). Соглашения были подписаны в ноябре 2007 г., в июле следующего года сделку закрыли.

Таким образом, к 2009 г. в электроэнергетике Иордании сложилась модель рынка с неполной конкуренцией, когда производители электроэнергии борются за право ее продажи существующей монополии (иногда такую модель называют «рынком единственного покупателя»). Структура отрасли, сложившаяся в Иордании после проведения реформ, представлена на рисунке 1 .

Еще одним способом привлечения иностранного капитала стало открытие электроэнергетики Иордании независимым производителям электроэнергии (НПЭ). Первым и пока единственным проектом такого рода стало строительство тепловой электростанции недалеко от Аммана с первоначальной мощностью 370 МВт. Этот проект «AES Jordan PSC» также известен под названием «Амманский восточный энергетический проект». Данная электростанция была введена в эксплуатацию 25 июля 2008 г. Собственники ТЭС: компании «AES Oasis Ltd.»-60\%, «Mitsui \& Co»-40\%. Вся производимая здесь электроэнергия закупается NEPCO согласно двадцатипятилетнему контракту. Стоимость проекта - 280 млн. долл. США. В 2009 г. электростанция достигла своей проектной мощности, в 2010 г. на ней было произведено 3,2 млрд. кВт·ч, или 22\% всей генерируемой электроэнергии в стране.

В настоящее время ведутся переговоры о строительстве новой электростанции мощностью 372 МВт в провинции Аль-Катрана, в 90 км к югу от Аммана. В октябре 2009 г. было подписано соглашение о финансировании 


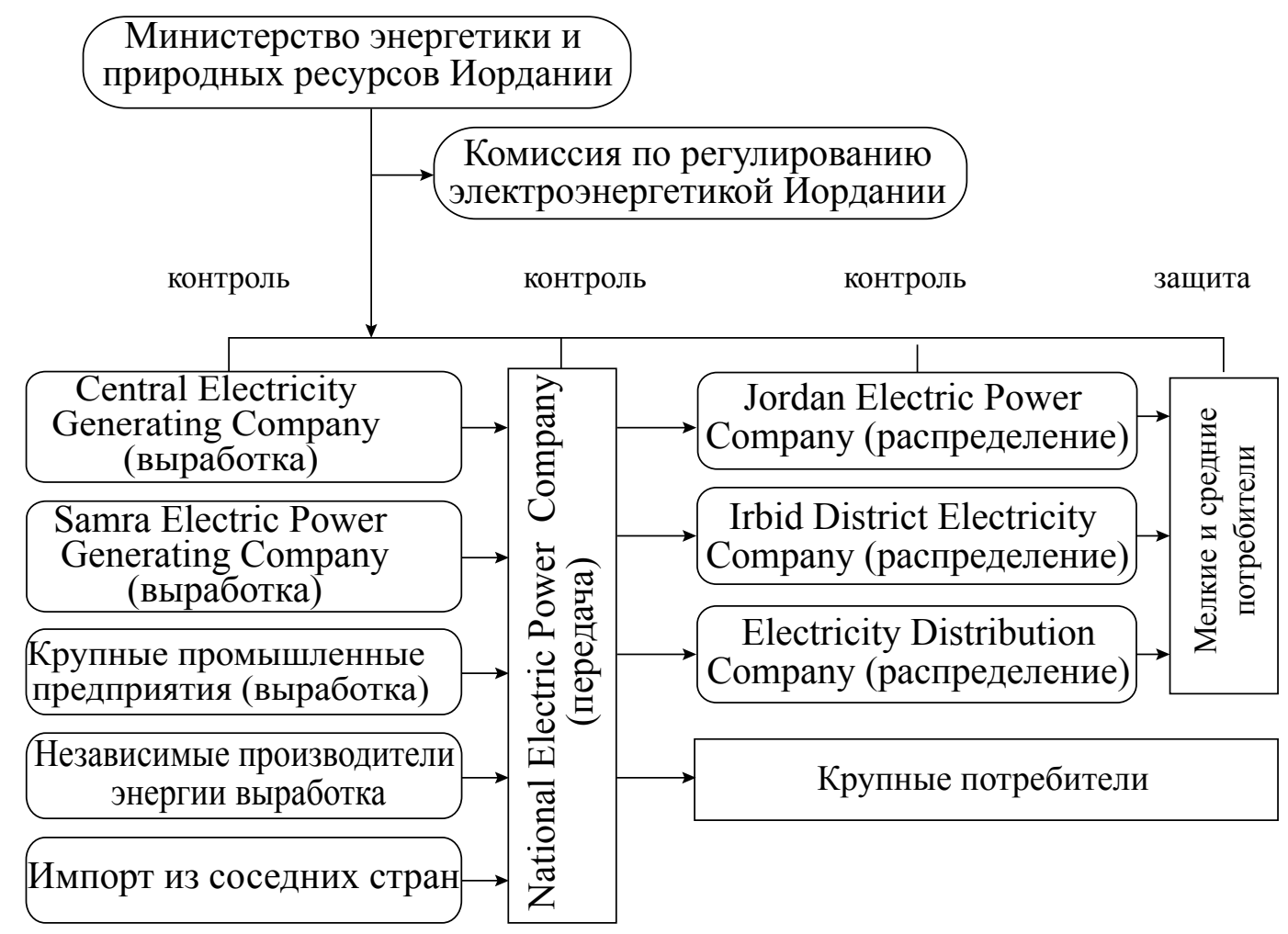

Рис. 1. Структура электроэнергетического сектора Иордании (составлено по [9])

проекта консорциумом, состоящим из корейской «Korea Electric Power Corporation» $(65 \%)$ и саудовской компании «Xenel Industries Ltd.» (35\%). Стоимость данного независимого энергетического проекта оценивается примерно в 3,1 млн. динар (4,4 млн. долл. США) [17]. Строительство объекта будет вести «Qatrana Electric Power Company». Новая электростанция будет работать на природном газе, доставляемом из Египта.

В настоящее время во всех странах, входящих в Совет сотрудничества арабских государств Персидского залива (ССАГПЗ), предприняты шаги по дерегулированию и приватизации электроэнергетического сектоpa, однако степень протекания данных процессов различна. В таблице 3 представлено современное состояние реформирования электроэнергетики в каждой из стран рассматриваемого региона.

Султанат Оман является признанным лидером в реформировании электроэнергетики среди стран региона. Фактически реформирование электроэнергетического хозяйства началось еще в 1996 г. после завершения первого независимого энергетического проекта: в эксплуатацию была введена электростанция «Манах», построенная компанией «United Power Company» на основе схемы «ВООТ» («строить - владеть - управлять - передавать»). В 2002 г. частные компании были приглашены для инвестирования в энергосистему «Салалах».

В 2005 г. был принят новый закон об электроэнергетике и водоснабжении, сформировавший правовую базу дальнейшей приватизации отрасли, ее открытия для частных инвесторов и создания независимого регулирующего органа. Закон предусматривал переход от вертикально-интегрированной к новой структуре рынка, а также разделение сфер генерации, передачи и распределения электроэнергии. В том же году было создано Управление по регулированию электроэнергетики.

В настоящее время в Омане рынок электроэнергии, структура которого представлена на рисунке 2, состоит из трех отдельных сегментов:

1) главная объединенная энергосистема на севере Омана; 


\section{Главная объединенная энергосистема Омана}

Выработка электроэнергии и опреснение воды

Al Rusail Power Company
SAOC

Wadi Al Jizzi Power Company SAOC

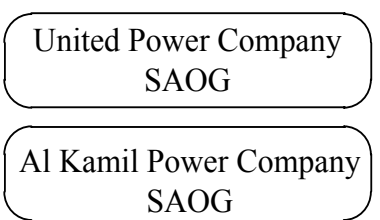

Al Ghubrah Power Company SAOC

AES Barka SAOG

Sohar Power Company SAOC
Снабжение водой и энергией

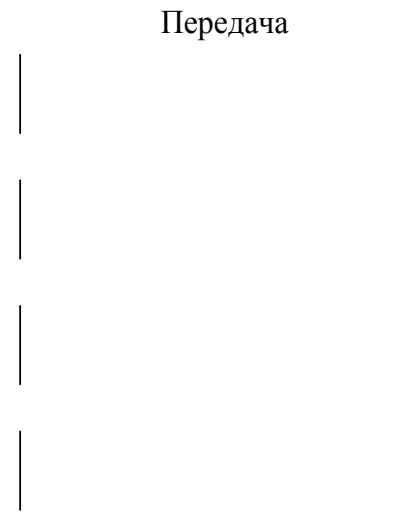

Oman Electricity Transmission Company SAOC

\section{Сельская энергосистема}

Rural Areas Electricity Company SAOC

\section{Энергосистема «Салалах»}

Dhofar Power Company SAOG

Рис. 2. Структура электроэнергетики Омана (составлено по [7]) 
Таблица 3

Современное состояние реформирования электроэнергетики в странах ССАГПЗ*

\begin{tabular}{|c|c|c|c|c|c|}
\hline Страна & $\begin{array}{c}\text { Вертикально- } \\
\text { инегрированная } \\
\text { структура }\end{array}$ & $\begin{array}{c}\text { Независимый } \\
\text { регулирующий } \\
\text { орган }\end{array}$ & $\begin{array}{c}\text { Разделение } \\
\text { сфер } \\
\text { Г, П и Р** }\end{array}$ & $\begin{array}{c}\text { Независимые } \\
\text { энергетические } \\
\text { проекты }\end{array}$ & $\begin{array}{c}\text { Модель } \\
\text { «одного } \\
\text { покупателя» }\end{array}$ \\
\hline Оман & нет & да & да & $\begin{array}{c}\text { в стадии } \\
\text { изучения }\end{array}$ \\
\hline $\begin{array}{c}\text { ОАЭ } \\
\text { Обу-Даби } \\
\text { эмильные }\end{array}$ & $\begin{array}{c}\text { нет } \\
\text { даты }\end{array}$ & $\begin{array}{c}\text { нет } \\
\text { нет }\end{array}$ & $\begin{array}{c}\text { да } \\
\text { нет }\end{array}$ & $\begin{array}{c}\text { да } \\
\text { нет }\end{array}$ & да \\
\hline $\begin{array}{c}\text { Саудовская } \\
\text { Аравия }\end{array}$ & частично & да & частично & да & да \\
\hline Катар & частично & нет & частично & да & $\begin{array}{c}\text { в стадии } \\
\text { изучения }\end{array}$ \\
\hline Бахрейн & да & $\begin{array}{c}\text { существуют } \\
\text { планы }\end{array}$ & $\begin{array}{c}\text { в стадии } \\
\text { изучения }\end{array}$ & да & нет \\
\hline Кувейт & да & нет & нет & нет & нет \\
\hline
\end{tabular}

* Составлено по материалам [12].

** Сферы генерации (Г), передачи (П) и распределения (Р).

2) сельская энергосистема, подконтрольная государственной компании «Rural Areas Electricity Company SAOC»;

3) энергосистема «Салалах», управляемая «Dhofar Power Company SAOG».

Внутри главной объединенной энергосистемы Омана восемь компаний занимаются выработкой электроэнергии, три из которых в свое время принадлежали государству. Одна из них — «Al Rusail» - была полностью приватизирована в 2006 г. посредствам продажи $100 \%$ ее активов, что стало первым подобным опытом в регионе. Это положило начало приватизации государственных энергокомпаний - процессу, который продолжается до сих пор.

Государственная компания «Oman Power and Water Procurement Company» является единственным покупателем электроэнергии у независимых производителей на всей территории Султаната. Она также занимается долгосрочным прогнозированием спроса, планирует ввод новых генерирующих мощностей и представляет проекты для НПЭ. Правительство не предполагает приватизи- ровать вышеуказанную компанию.

В сфере передачи электроэнергии в Омане функционирует «Oman Electricity Transmission Company», которая владеет и управляет системой ЛЭП напряжением 220 и 132 кB. В 2008 г. специалисты «KPMG» были приглашены для проведения контроля над приватизацией компании, однако мировой финансовый кризис приостановил процесс. Правительство также заявило о намерениях передать в частные руки три распределительные компании. Структура собственности в электроэнергетике Омана представлена на рисунке 3.

Среди семи эмиратов, входящих в состав $O A Э$, наибольших успехов в деле приватизации и дерегулирования добился крупнейший эмират Абу-Даби. Рассматриваемые процессы начались здесь еще в 1990-х гг. До 1999 г. сектор имел вертикально-интегрированную структуру и полностью принадлежал государству. В 1998 г. был принят новый закон, положивший начало реформированию электроэнергетики, путем создания так называемой модели «одного покупателя». 


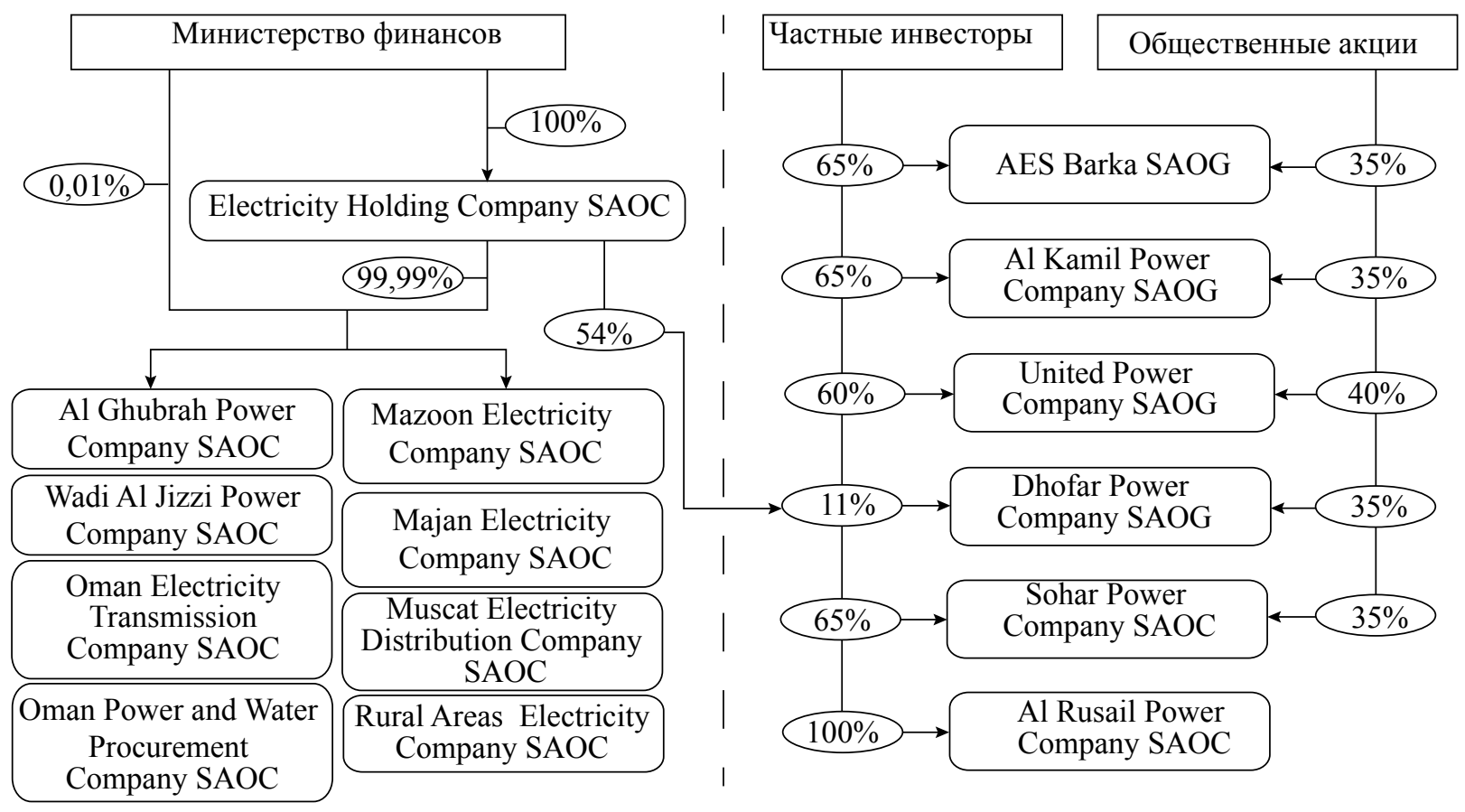

Рис. 3. Структура собственности в электроэнергетическом хозяйстве Омана (по состоянию на 2009 г., составлено по [11])

Согласно новому закону, в сфере электроэнергетики и водоснабжения были учреждены следующие компании:

- четыре компании по производству электроэнергии и опреснению морской воды;

- компания, которая занимается закупками электроэнергии и воды у производителей и последующей продажей продукта распределительным компаниям; и воды;

— компания по передаче электроэнергии

- две распределительные компании, отвечающие за снабжение электроэнергией и водой конечных потребителей;

- независимый орган, ответственный за экономическое и техническое регулирование отраслей.

В Абу-Даби разрешена также деятельность независимых производителей электроэнергии и воды. В настоящее время на территории эмирата действуют девять таких компаний. Правительство приватизировало некоторые из них, в то время как сферы передачи и распределения остаются в руках государства.
В остальных шести эмиратах ОАЭ на сегодняшний момент не существует конкретных планов по реформированию электроэнергетики и водоснабжения.

В Саудовской Аравии в 2000 г. королевским указом была создана «Саудовская электрическая компания», которая объединила десять региональных энергокомпаний, ранее снабжавших Королевство электроэнергией. Также правительство разрешило частному сектору инвестировать в производство электроэнергии. Создание компании «Марафик» для снабжения электроэнергией и пресной водой промышленных городов Янбу и Джубайл, а также создание «Водной и электрической корпорации» в западной провинции страны стали основным стимулом для дальнейшего дерегулирования и приватизации отрасли.

В рамках процесса реформирования в ноябре 2001 г. было создано Управление по регулированию электроэнергетики, ответственное за регулирование поставок электроэнергии потребителям, выдачу лицензий на электроэнергетические проекты, обеспече- 
ние соблюдения условий лицензий, а также защиту прав потребителей, инвесторов, производителей и дистрибьюторов.

План по реформированию электроэнергетического хозяйства, принятого на период с 2008 по 2016 гг., можно разделить на три этапа:

Разделение сфер производства, передачи и распределения электроэнергии, путем расформирования «Саудовской электрической компании» и создания новых компаний;

Создание конкурентного оптового рынка электроэнергии;

Создание конкурентного розничного рынка электроэнергии.

В настоящее время в Саудовской Аравии разрешена деятельность независимых производителей электроэнергии, кроме того, крупные промышленные потребители имеют право устанавливать свои собственные генерирующие мощности, а остатки электроэнергии продавать в общую сеть, принадлежащую «Саудовской электрической компании».

Правительство Катара уже приступило к осуществлению программы по реформированию и приватизации электроэнергетического сектора. Было разрешено функциональное разделение производства, передачи и распределения электроэнергии, а также участие частного сектора.

В ведении «Главной корпорации Катара по электроэнергетике и водным ресурсам» («Kahramaa») остается передача и распределение электроэнергии, в то время как генерация была передана вновь образованной «Электроэнергетической и водной компании Катара». Правительство выдает лицензии частному сектору на строительство электростанций, и в настоящее время изучает возможность приватизации «Kahramaа» и создания компании по передаче и распределению электроэнергии.

Министерство энергетики и водных ресурсов Бахрейна несет ответственность за производство, передачу и распределение электроэнергии, однако и в этом Королевстве предприняты первые шаги по реформированию энергетического сектора.

Переходя от вертикально-интегрированной структуры отрасли к модели «одного покупателя», правительство разрешило участие частного сектора в сфере производства элек- троэнергии, а также приватизировало электростанции «Аль-Хидд» и «Аль-Эззель». Также в стране планируется создание независимого регулирующего органа.

Энергетический сектор Kувейта полностью находится под контролем Министерства энергетики, отвечающего за его работу, развитие и расширение. Электроэнергетические объекты находятся в государственной собственности, а отрасль имеет вертикальноинтегрированную структуру. Несмотря на то, что темпы роста потребления электроэнергии в Кувейте - одни из самых высоких в регионе Персидского залива, правительство страны до сих пор не имеет никакой программы по реформированию электроэнергетического сектора.

Таким образом, основными направлениями реформирования электроэнергетического хозяйства стран ССАГПЗ являются формирование конкуренции в сфере производства электроэнергии путем разрешения деятельности независимых ее производителей, а также разделение сфер генерации, передачи и распределения.

В Сирии электроэнергетика является государственной монополией, и в настоящее время не существует каких-либо конкретных планов по ее реструктуризации и приватизации. По оценкам специалистов Социальноэкономической комиссии ООН по Западной Азии, электроэнергетическая отрасль останется в руках государства в течение как минимум 10 лет. Однако это не означает, что в Сирии не предпринимаются меры по привлечению в электроэнергетику иностранных инвестиций, без изменения отношений собственности в данной отрасли. Чтобы привлечь необходимый капитал для строительства новых и модернизации уже имеющихся электростанций, сирийское правительство открыло сектор независимым производителям электроэнергии. Данная тенденция в развитии отрасли опирается на новое инвестиционное законодательство, принятое в 2007 г.

В июне 2006 г. иранская «Azrab Energy Industries Development Company» подписала договор на строительство и эксплуатацию электростанции «Сувейдия» мощностью 450 МВт. Она была завершена в середине 2009 г. В этом же году была пущена электростанция комбинированного типа «Дейр 
аз-Зор» мощностью 750 МВт, построенная испано-польским объединением компаний «Iberola» и «Alstom Poland». В мае 2008 г. введена в эксплуатацию ТЭС «Дейр Али» мощностью 750 МВт, сооруженная немецким совместным предприятием, созданным компаниями «Siemens» и «Koch». Вышеназванные электростанции, работающие на природном газе, стали первыми в стране независимыми энергетическими проектами.

В Ливане деловая среда, в отличие от других арабских стран, всегда базировалась в основном на принципах свободного рынка. Тем не менее, электроэнергетика находилась в государственной собственности. В 1954 г. была основана компания «Electricité du Liban» (EDL), которая и в настоящее время продолжает осуществлять монопольное право на производство, передачу и распределение электроэнергии. Однако частный сектор все же присутствует в электроэнергетической отрасли страны: EDL предоставила концессии на распределение электроэнергии двум небольшим компаниям в районе городов Захля, Бхамдоун, Алея, Джубейль.

Участие частного капитала до сих пор осуществлялось не в рамках общей стратегии приватизации, а в большей мере, как промежуточные шаги в ожидании реструктуризации сектора. В 2002 г. в Ливане был разработан и принят новый закон об электроэнергетике, в соответствии с которым отрасль была открыта для независимых производителей электроэнергии. Правительство подписало соглашение на строительство двух частных электростанций. Позднее, в 2005-2006 гг. были проведены тендеры по выдаче концессий частным инвесторам на эксплуатацию и поддержание распределительных сетей, а также на обновление системы учета электроэнергии и сбора платежей, в частности модернизацию и замену счетчиков.

В Ливане реформирование электроэнергетики считается одной из важнейших народно-хозяйственных задач, без решения которой нельзя обеспечить поступательный прогресс национальной экономики, ее обновление и преодоление последствий многолетней гражданской войны. Дерегулирование и приватизация электроэнергетики рассматривается и как главный способ выхода из затяжного кризиса, в котором отрасль находится с конца XX в. С помощью реформ планируется решить проблемы нехватки генерирующих мощностей, больших технических и нетехнических потерь, а также недостаточного развития передающей и распределительной сети.

При участии специалистов Всемирного банка был подготовлен проект по реструктуризации энергетического сектора, который призывал к осуществлению ряда общеструктурных реформ отрасли, направленных на развитие конкуренции. В 2002 г. ливанский парламент принял закон о приватизации электроэнергетики. В соответствии с ним до 40\% активов компании EDL предполагалось продать стратегическому партнеру, участие которого не ограничивалось бы только стадией производства электроэнергии, но и включало стадию распределения, в том числе учет потребления электроэнергии, выставление счетов за пользование электроэнергией и прием платежей. В государственной собственности должны были остаться лишь магистральные линии электропередачи. Однако планы приватизации пришлось отложить.

В 2008 гг. правительство вернулось к принятому закону и стало разрабатывать механизм его действия. Скорее всего, EDL превратится в акционерное общество, контрольный пакет акций которого останется в руках государства. Также планируется разрешить частному сектору производить электроэнергию и продавать ее либо государству в лице этой компании, либо напрямую потребителям.

В июле 2012 г. палата представителей Ирака единогласно проголосовала за проект приватизации электроэнергетики в стране.

Власти Йемена также планируют провести реформирование отрасли в ближайшем будущем, однако каких-либо конкретных проектов законов в открытом доступе на сегодняшний момент не существует.

В таблице 4 представлена информация о производстве и потреблении электрической энергии в энергосистемах арабских странах Западной Азии в 2010 г.

Следует отметить, что электроэнергетический комплекс арабских стран Западной Азии в настоящее время практически полностью обеспечивает потребность в электроэнергии. Вместе с тем, в рассматриваемом регионе наблюдается устойчивый рост чи- 
Таблица 4

Баланс электрической энергии в энергосистемах арабских странах Западной Азии в 2010 г., млрд. кВт·ч*

\begin{tabular}{|l|c|c|c|c|}
\hline \multicolumn{1}{|c|}{ Страна } & $\begin{array}{c}\text { Выработанная } \\
\text { электроэнергия }\end{array}$ & $\begin{array}{c}\text { Потребленная } \\
\text { электроэнергия }\end{array}$ & $\begin{array}{c}\text { Экспорт } \\
\text { электроэнергии }\end{array}$ & $\begin{array}{c}\text { Импорт } \\
\text { электроэнергии }\end{array}$ \\
\hline Иордания & 14,777 & 12,843 & 0,058 & 0,67 \\
\hline ОАЭ & 88,184 & 84,404 & 8,051 & Инф. отсутств. \\
\hline Бахрейн & 13,23 & 12,142 & 0,019 & 0,192 \\
\hline СА & 239,892 & 212,263 & Инф. отсутств. & Инф. отсутств \\
\hline Сирия & 46,413 & 33,654 & 1,043 & 0,69 \\
\hline Ирак & 48,906 & 31,951 & Инф. отсутств & 6,153 \\
\hline Катар & 26,362 & 25,67 & 0,059 & 0,043 \\
\hline Кувейт & 57,029 & 50,136 & 0,137 & 0,073 \\
\hline Ливан & 11,211 & 10,59 & Инф. отсутств & 1,249 \\
\hline Йемен & 6,4 & 5,036 & Инф. отсутств & 1,357 \\
\hline ИТОГО: & $\mathbf{5 5 2 , 4 0 4}$ & $\mathbf{4 7 8 , 6 8 9}$ & & \\
\hline
\end{tabular}

* Составлено и рассчитано по материалам [16].

сленности населения, причем темпы роста существенно превышают средние показатели по миру. Учитывая изложенное, а также тот факт, что эти государства обладают большими запасами углеводородов, можно предположить: в перспективе потребность в электроэнергии здесь будет расти.

В таблице 5 представлена информация о перспективах развития электроэнергетического сектора рассматриваемых стран.

Анализ информации, представленной в таблице 5, показывает, что потребность в электроэнергии во всех арабских странах Западной Азии в перспективе имеет устойчивый рост. В частности, суммарная потребность в электроэнергии данных государств в 2020 г. превысит объем потребленной энергии этими странами в 2011 году в 2 раза.

Учитывая факт ориентированности энергетических стратегий арабских стран Западной Азии на создание самодостаточных электроэнергетических комплексов, можно предположить, что руководство государств инициирует строительство недостающих генерирующих мощностей. Это сформирует на период до 2020 г. чрезвычайно устойчивый энергетический рынок, интерес к которому будут иметь все электроэнергетические компании мира, в том числе и российские.

Российские электроэнергетические компании продолжают вести деятельность во всех традиционных странах-партнерах по энергетическому диалогу, но наиболее активно они работают в электроэнергетике Ирака.

Летом 2005 г. российские компании «Интерэнергосервис» и «Энерго Инжиниринг Энтерпразиз» вновь возобновили работу в Ираке. В настоящее время они реализуют контракты на восстановление теплоэлектростанции в пригороде Багдада. ОАО «ВО «Технопромэкспорт» в 2008 г. выиграло тендер на восстановление «под ключ» двух из трех блоков ТЭС «Харта», мощностью 200 МВт каждый, и в 2009 г. подписало соответствующий контракт. Ввод объектов в эксплуатацию намечен на четвертый квартал 2012 г. В 2009 г. ОАО «Инженерный центр ЕЭС» и ООО «Сервисная Энергетическая Компания» выиграли тендер на реконструкцию блоков №3 и №4 ТЭС «Нассирия» с увеличением мощности каждого энергоблока со 110 до 180 МВт, а также на восстановление 
Таблица 5

Прогноз развития электроэнергетического сектора арабских стран Западной Азии до 2020 г.*

\begin{tabular}{|c|c|c|c|c|c|c|}
\hline \multirow{2}{*}{ Страна } & \multicolumn{2}{|c|}{2011 г. } & \multicolumn{2}{c|}{2015 г. } & \multicolumn{2}{c|}{2020 г. } \\
\cline { 1 - 7 } & $\begin{array}{c}\text { Выработан- } \\
\text { троя элек- } \\
\text { млрд } \\
\text { кВт·ч }\end{array}$ & $\begin{array}{c}\text { Макси- } \\
\text { мальный } \\
\text { спрос, } \\
\text { МВт }\end{array}$ & $\begin{array}{c}\text { Потреб- } \\
\text { ность в } \\
\text { электро- } \\
\text { энергии, } \\
\text { млрд } \\
\text { кВт·ч }\end{array}$ & $\begin{array}{c}\text { Макси- } \\
\text { мальный } \\
\text { спрос, } \\
\text { МВт }\end{array}$ & $\begin{array}{c}\text { Потреб- } \\
\text { ность в } \\
\text { электро- } \\
\text { энергии, } \\
\text { млрд } \\
\text { кВт·ч }\end{array}$ & $\begin{array}{c}\text { Макси- } \\
\text { мальный } \\
\text { спрос, } \\
\text { МВт }\end{array}$ \\
\hline $\begin{array}{c}\text { Иорда- } \\
\text { ния }\end{array}$ & 16 & 2812 & 21,1 & 3662 & 29,6 & 4979 \\
\hline $\begin{array}{c}\text { Бах- } \\
\text { рейн }\end{array}$ & 15,3 & 3000 & 22,5 & 4507 & 37,8 & 7783 \\
\hline СА & 247 & 46110 & 320,3 & 61500 & 443,8 & 77430 \\
\hline Сирия & 50,3 & 8318 & 64,7 & 10632 & 88,5 & 14431 \\
\hline Ирак & 61,3 & 14500 & 165 & 18500 & 200 & 25000 \\
\hline Катар & 26,7 & 5561 & 34,7 & 7197 & 43,38 & 8883 \\
\hline Кувейт & 61,6 & 11716 & 79,2 & 15110 & 116 & 22193 \\
\hline Ливан & 16,2 & 2610 & 19 & 3054 & 23,1 & 3715 \\
\hline Йемен & 8 & 1250 & 10 & 1551 & 15,3 & 2390 \\
\hline Итого: & $\mathbf{5 0 2 , 4}$ & $\mathbf{9 5 8 7 7}$ & $\mathbf{7 3 6 , 5}$ & $\mathbf{1 2 5 7 1 3}$ & $\mathbf{9 9 7 , 4 8}$ & 166804 \\
\hline
\end{tabular}

* Составлено и рассчитано по материалам [16].

ТЭС в г. Басре. В 2010 г. российско-швейцарская компания «Wintercroft Capital» подписала соглашение с руководством иракской провинции Майсан о строительстве двух ТЭС общей мощностью 1150 МВт, которые смогут решить проблемы, связанные с нехваткой электроэнергии.

В Сирии российские компании принимали участие в тендерах на расширение ТЭС «Тишрин», строительство гидроэнергетического комплекса «Халябия-Залябия» на реке Евфрат и крупного ирригационного комплекса на реке Тигр. Однако в настоящее время нет информации о реализации каких-либо конкретных проектов в сфере электроэнергетики на территории Сирии.

На юге Йемена компания «Технопромэкспорт» в 2004-2008 гг. поставляла запчасти для ТЭС «Аль-Хисва», в настоящее время совместно с ОАО «ИНТЕР РАО ЕЭС» ведет переговоры с йеменской стороной об осуществлении капитального ремонта этой станции.

Здесь необходимо отметить произошедшую смену лидера: сегодня наиболее активные шаги по углублению кооперации с арабскими странами предпринимает ОАО «ИНТЕР РАО ЕЭС». Информация о ходе проектов, осуществляемых вышеуказанной компанией на Ближнем Востоке, приведена в таблице 6.

В настоящее время основной задачей ОАО «ИНТЕР РАО ЕЭС» по указанным объектам является сбор исходных данных об объемах и состоянии поставленного и смонтированного оборудования, запасных частей и материалов, а также результатах ранее выполненных строительно-монтажных работ.

В 2009 г. российская компания подавала заявку на участие в тендерах на строительст- 
Таблица 6

Электроэнергетические проекты, реализуемые ОАО «ИНТЕР РАО ЕЭС» в арабских странах

\begin{tabular}{|c|c|c|c|c|c|c|}
\hline $\begin{array}{c}\text { Стра- } \\
\text { на }\end{array}$ & Проект & $\begin{array}{c}\text { Участники } \\
\text { проекта }\end{array}$ & $\begin{array}{c}\text { Условия фи- } \\
\text { нансирования }\end{array}$ & $\begin{array}{c}\text { Объем работ } \\
\text { и состав обо- } \\
\text { рудования }\end{array}$ & $\begin{array}{c}\text { Стои- } \\
\text { мость } \\
\text { контрак- } \\
\text { та (млн. } \\
\text { долл. } \\
\text { США) }\end{array}$ & $\begin{array}{c}\text { Сроки под- } \\
\text { писания } \\
\text { договора, } \\
\text { реализации } \\
\text { проекта }\end{array}$ \\
\hline $\begin{array}{l}\text { Си- } \\
\text { рия }\end{array}$ & $\begin{array}{c}\text { ТЭС } \\
\text { «Трифа- } \\
\text { ви» } \\
(250 \\
\text { МВт) }\end{array}$ & $\begin{array}{l}\text { Мини- } \\
\text { стерство } \\
\text { энергетики } \\
\text { Сирии, де- } \\
\text { партамент } \\
\text { PEEG }\end{array}$ & $\begin{array}{c}\text { Прорабатыва- } \\
\text { ются }\end{array}$ & $\begin{array}{c}\text { Поставка все- } \\
\text { го оборудова- } \\
\text { ния, монтаж, } \\
\text { пуск в эксплу- } \\
\text { атацию }\end{array}$ & $750-940$ & $\begin{array}{c}\text { Подписание: } \\
\text { декабрь } 2012 \\
\text { (возможны } \\
\text { корректиров- } \\
\text { ки). } \\
\text { Реализация: } \\
40 \text { месяцев }\end{array}$ \\
\hline Ирак & $\begin{array}{c}\text { ГЭС } \\
\text { «Аль } \\
\text { Адаим» } \\
(27,4 \\
\text { МВт) }\end{array}$ & $\begin{array}{c}\text { Мини- } \\
\text { стерство } \\
\text { энергетики } \\
\text { Ирака }\end{array}$ & $\begin{array}{c}\text { Бюджетные } \\
\text { средства ирак- } \\
\text { ской стороны }\end{array}$ & $\begin{array}{c}\text { Допоставка } \\
\text { основного } \\
\text { оборудования } \\
\text { (гидроагрегат, } \\
\text { генераторы } \\
\text { единичной } \\
\text { мощностью } \\
\text { 13,6 МВт), } \\
\text { монтаж, пу- } \\
\text { ско-наладка и } \\
\text { пуск станции }\end{array}$ & $\begin{array}{c}\text { В случае } \\
\text { исполне- } \\
\text { ния } \\
\text { ПНР - } \\
42\end{array}$ & $\begin{array}{c}\text { Подписание: } \\
\text { август-сен- } \\
\text { тябрь } 2012 \\
\text { (возможны } \\
\text { корректиров- } \\
\text { ки). } \\
\text { Реализация: } \\
23 \text { месяца }\end{array}$ \\
\hline Ирак & $\begin{array}{c}\text { ТЭС } \\
\text { «Дибис» } \\
(2 \times 160 \\
\text { МВт) }\end{array}$ & $\begin{array}{c}\text { Мини- } \\
\text { стерство } \\
\text { энергетики } \\
\text { Ирака }\end{array}$ & $\begin{array}{c}\text { Бюджетные } \\
\text { средства }\end{array}$ & $\begin{array}{c}\text { Допоставка } \\
\text { вспомога- } \\
\text { тельного } \\
\text { оборудования, } \\
\text { монтаж, пу- } \\
\text { ско-наладка и } \\
\text { пуск станции }\end{array}$ & $75-80$ & $\begin{array}{c}\text { Подписание: } \\
\text { сентябрь } \\
2012 \\
\text { (возможны } \\
\text { корректиров- } \\
\text { ки). } \\
\text { Реализация: } \\
30 \text { месяцев }\end{array}$ \\
\hline
\end{tabular}


во йеменских ТЭС «Мариб-2» и «Мариб-3». Сейчас «Технопромэкспорт» прорабатывает с йеменской стороной вопросы участия в сооружении новых объектов электроэнергетики, в том числе ТЭС «Маабар» мощностью 400 МВт; ТЭС «Бальхаф» мощностью 800 МВт; ТЭС для нефтеперерабатывающего завода (НПЗ) города Адена мощностью 18 МВт.

Однако отечественные компании не только поддерживают связи с традиционными партнерами, доставшими в наследство от Советского Союза, но и устанавливают новые контакты.

Так, в Иордании ОАО «ИНТЕР РАО ЕЭС» реализует проект по строительству комплекса по переработке сланца. В Ливане был изучен проект сетевого строительства - линий электропередачи, а также получено приглашение для прохождения предквалификации ${ }^{1}$ как компании, имеющей опыт в строительстве и эксплуатации электростанций на газе с комбинированным циклом.

Новыми и весьма перспективными для российских компаний могут стать электроэнергетические рынки стран Персидского залива. На данный момент у России нет подписанных контрактов в рассматриваемом регионе, однако шаги по налаживанию сотрудничества были предприняты.

В июне 2009 г. состоялось подписание между ЗАО «ВТБ Капитал», ОАО «ИНТЕР PAО ЕЭС» и кувейтской частной компанией «Fouad Alghanim and Sons Co.» соглашения о намерениях с целью создания совместного фонда, инвестирующего в инфраструктурные проекты, прежде всего в электроэнергетику, на территории России, стран СНГ и Ближнего Востока. Тогда российская сторона отметила заинтересованность «ИНТЕР РАО ЕЭС» рассмотреть предложения Кувейтской стороны по участию в реализации проектов строительства новых и модернизации действующих электростанций, а также их управления, эксплуатации и приватизации на территории своего государства.

В ноябре того же года между ОАО «ИНTЕР РАО ЕЭС» и электроэнергетической компанией «Abu Dhabi Water and Electricity Authority» был подписан меморандум о намерениях по сотрудничеству в сфере электроэнергетики, предполагающий кооперацию сторон в совместном инвестировании проектов на территории Ближнего Востока. С эмиратской компанией обсуждается и изучается возможность участия Общества в электроэнергетических проектах на территории ОАЭ. В феврале 2011 г. было открыто представительство «ИНТЕР РАО ЕЭС» в г. Абу-Даби.

ОАО «Силовые машины» проводит мониторинг перспектив работы в электроэнергетическом секторе ОАЭ, компания готова участвовать в возможных тендерах на поставку материалов и оборудования для строительства электростанций в ОАЭ.

В июне 2011 г. ОАО «ИНТЕР РАО ЕЭС» получило от саудовской компании «Alrasim United Company» предложение по сотрудничеству в сфере электроэнергетики.

В настоящее время также идет подготовка к регистрации ОАО «ВО «Технопромэкспорт» в Саудовской Аравии для последующего ее участия в строительстве энергетических объектов на территории Королевства. Также ОАО «ВО «Технопромэкспорт» и «Силовые машины» выражают заинтересованность в совместной деятельности с саудовскими компаниями в энергетических проектах на территории третьих, в том числе соседних, государств.

Необходимо отметить, что арабские нефтедобывающие государства обладают серьезными финансовыми ресурсами и могут выступить инвесторами российской энергетики. Катар и Кувейт уже выразили свою готовность рассмотреть предложения российской стороны.

Проведенное научное исследование позволяет сформулировать следующие выводы:

1. Показано, что процессы реструктуризации и разгосударствления электроэнергетики в арабских странах Западной Азии сформировали в настоящее время их энергетический рынок.

2. Доказано, что энергетический рынок в арабских странах Западной Азии на пери-

1 Согласно законодательству Ливанской Республики, для возможности участия компании в тендерах, проводимых в стране, требуется пройти предварительную квалификацию в Министерстве энергетики и водных ресурсов. 
од до 2020 г. характеризуется устойчивым ростом, интерес к которому будут иметь все электроэнергетические компании мира, в том числе и российские.

3. Показано, что расширение присутствия российских энергетических компаний на электроэнергетическом рынке арабских стран Западной Азии возможно за счет усиления взаимовыгодной кооперации как с отечественными, так и с зарубежными компаниями.

\section{Литература}

1. Арсюхин Е. Россия простит Сирии 10 миллиардов долларов долга [Электронный pecypc] / Российская газета. - Режим доступа: http://www.rg.ru/2005/01/25/dolg-anons. html, свободный (25.01.2005). - Загл. с экрана.

2. Дерябина М. Реформирование естественных монополий: теория и практика. // Вопросы экономики. — 2006. - №1.

3. Конищева T. Прощание с долгом [Электронный ресурс] / Российская газета. Режим доступа: http://www.rg.ru/2008/02/12/ irak.html, свободный (12.08.2012). — Загл. с экрана.

4. Приказ Минэнерго России от 13.08.2012 №387 «Об утверждении схемы и программы развития Единой энергетической системы России на 2012-2018 годы» [Электронный ресурс] / Минэнерго. - Режим доступа: http://minenergo.gov.ru/documents/ fold13/index.php?ELEMENT_ID=13092, свободный. - Загл. с экрана.

5. «Технопромэкспорт» [Электронный ресурс] / Официальный сайт. - Режим доступа: http://www.tpe.ru/, свободный. - Загл. с экрана.

6. Arafeh M., Aburas R., Kharbat F. The Privatization of the Electricity Supply Industry in Jordan // 17th World energy Congress. Houston, USA, 1998.

7. Authority for Electricity Regulation, Oman [Электронный pecypc] / Official Webpage. - Режим доступа: http://www.aeroman.org/, свободный. - Загл. с экрана.

8. Wardam B. Hydropower Energy in Jordan. // Arab Environment Watch. - 2006. №7.
9. Central Electricity Generating Company (CEDCO) [Электронный pecypc] / Official Webpage. - Режим доступа: http://www. cegco.com.jo/?q=en/node/46, свободный. Загл. с экрана.

10. Country Focus: Oman - Sultanate of swing [Электронный pecypc] / Power Engineering International. - Режим доступа: http://www.powerengineeringint.com/articles/ mee/print/volume-3/issue-4/features/countryfocus-oman-sultanate-of-swing.html, свободный (01.12.2006). - Загл. с экрана.

11. Cunneen J. Emerging Markets - Middle East. // APEx Conference. - Dublin, 2010.

12. Al-Asaad H. K., Al-Mohaisen A. I., Sud S. GCC Power Grid: Transforming the GCC Power Sector into a Major Energy Trading Market [Электронный pecypc] / Gulf Cooperation Council Interconnection Authority. - Режим доступа: http://www.gccia.com.sa/ articles/Paper-Cigre.pdf, свободный. - Загл. с экрана.

13. Karim A. M. H. A., Maskati N. H. A., Sud $S$. Status of Gulf co-operation council (GCC) electricity grid system interconnection. // Power Engineering Society General Meeting. Vol. 2. Denver, 2004. - Pp. 1385-1388.

14. El-Katiri L. Interlinking the Arab Gulf: Opportunities and Challenges of GCC Electricity Market Cooperation. // The Oxford Institute for Energy Studies. - Oxford, 2011.

15. Hitchin $P$. Oman leads Gulf States in reform and privatization of electricity and water sectors [Электронный pecypc] / Power Engineering International. - Режим доступа: http:/www.powerengineeringint.com/articles/ mee/print/volume-8/issue-1/features/omanleads-gulf-states-in-reform-and-privatization. html, свободный (30.06.2011). - Загл. с экрана.

16. Statistical Bulletin 2010, Issue 19 [Электронный ресурс] / Arab Union of Electricity. - Режим доступа: http://www.auptde.org/ PublicationsCat.aspx?lang=en $\& \mathrm{CID}=95, \quad$ свободный. - Загл. с экрана.

17. The World Bank [Электронный peсурс] / Официальный сайт Организации. Режим доступа: http://www.worldbank.org/ projects/P108850/al-qatrana-power?lang=en, свободный. - Загл. с экрана. 


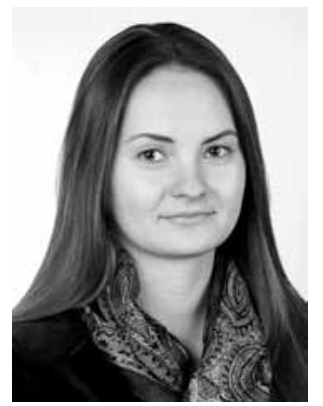

Анна Юрьевна Шарова - аспирант Института стран Азии и Африки при Московском государственном университете им. Ломоносова.

Anna Yurievna Sharova - postgraduate student at the Moscow State University of Lomonosov name Institute of Asian and African Studies.

125009 , г. Москва, ул. Моховая, 11, стр. 1

11 Mokhovaya st., bld. 1, 125009, Moscow, Russia

Тел.: +7 (916) 900-78-52; e-mail:9007852@gmal.com

\section{Международная научно-практическая конференция \\ «ВЗАИМОДЕЙСТВИЕ ГОСУДАРСТВЕННЫХ И КОРПОРАТИВНЫХ УЧЕБНЫХ ЗАВЕДЕНИЙ КАК РЕСУРС ПОВЫШЕНИЯ КАЧЕСТВА ПРОФЕССИОНАЛЬНОГО ОБРАЗОВАНИЯ» с изданием сборника материалов конференции}

Основные проблемы, обсуждаемые на конференции:

1. Производственное обучение и производственные практики студентов на предприятиях в условиях реализации новых ФГОС: опыт, проблемы, качество.

2. Качество подготовки компетентных специалистов в условиях частно-государственного партнерства предприятий и учебных заведений.

3. Корпоративное обучение на предприятии и обучение в учебном заведении: точки взаимодействия.

4. Уровневое образование и требования предприятий: качество подготовки и востребованность выпускников.

5. Обучение инновационному предпринимательству в условиях взаимодействия государственного и корпоративного профессионального образования.

6. Научно-методическое обеспечение взаимодействия государственного и корпоративного профессионального образования.

Для участия в конференции необходимо представить заявку, тезисы доклада на бумажном и электронном носителях по адресу:

420043, г. Казань, ул. Зеленая, д. 1, Казанский государственный архитектурно-строительный университет, факультет инженерных систем и экологии, кафедра профессионального обучения и педагогики, корпус 3 , ком. 309

или: 420039, г. Казань, ул. Исаева, д. 12, ИПП ПО РАО, ком. 306 